UDC 811.111'25+81'373.2

DOI https://doi.org/10.24919/2308-4863/41-3-19

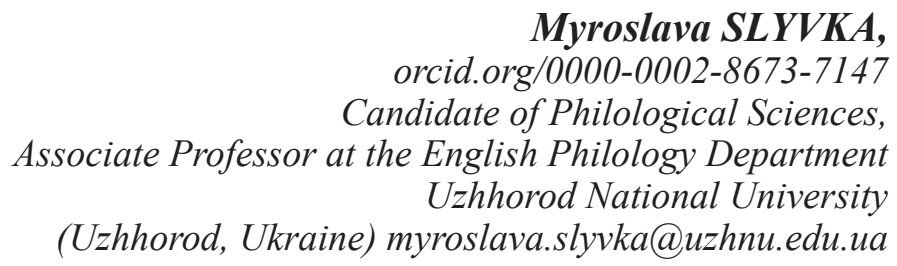

Nataliia SLYVKA, orcid.org/0000-0001-7894-8553

Senior Teacher at the Foreign Languages Department Uzhhorod National University (Uzhhorod,Ukraine) nataliia.slyvka@uzhnu.edu.ua

Iryna ANDRUSIAK, orcid.org/0000-0002-3377-9706

Candidate of Philological Sciences, Associate Professor at the English Philology Department Uzhhorod National University (Uzhhorod, Ukraine) iryna.andrusiak@uzhnu.edu.ua

\title{
REPRODUCTION SPECIFICITIES OF REALIAS OF HISTORY AND CULTURE OF UKRAINE IN THE TRANSLATION OF YURIJ ANDRUKHOVYCH'S NOVEL "THE MOSKOVIAD" INTO ENGLISH
}

The article is devoted to the analysis of rendering specificities of Ukrainian realia words in the English translation by the example of the novel "The Moscoviad" by Yuri Andrukhovych. The aim of article is to conduct the comprehensive analysis of pragmatic and hermeneutic aspects of Ukrainian realia translation. Due to the considerable discrepancies in terms of scientific views in this sphere the rules of Ukrainian realia words and proper names translation require standardization. The article explains the necessity of taking into consideration the pragmatic aspect and interpretive potential from the point of view of hermeneutics in the process of historico-cultural nominations translation, analyses the contextual links within a given text to determine the scope of national colouring of a particular realia in it. The study establishes functional and pragmatic aspects of the nationally coloured words usage and translation in literary text. The authors of the article examine the cases of abuse and preserving of the national colour of Ukrainian geographic and ethnographic realias while translating from English into Ukrainian. We determine the primary ways of conveying different realias of history and culture of Ukraine in the novel. The research has demonstrated that the commonest ways of rendering realias are combined renomination, descriptive paraphrase, transcription (transliteration), calquing and hyponym translation (generalization). The authors conclude that the usage of combined renomination in realia translation provide information not only about a particular realia, but also reflect a variety of specific features of national outlook and ethnic ways of the "linguistic mapping" of the reality. The authors define the correspondence level of connotative nationally marked information representation. The article has shown that communicative interpretation of the source language term and its contextual implications depends very much on the profound analysis of context and cultural background of the author or translator of the original text.

Key words: translation, nationally coloured words, realia, pragmatic aspect, hermeneutic aspects, transcription, combined renomination.

Мирослава СЛИВКА, orcid.org/0000-0002-8673-7147 кандидат філологічних наук, доиент кафедри англійської філології

Ужсгородського національного університету (Украӥна Ужгород) myroslava.slyvka@uzhnu.edu.ua 
Наталія СЛИВКА,

orcid.org/0000-0001-7894-8553

ст.викладач кафедри іноземних мов

Ужсгородського начіонального університету

(Украӥна Ужгород) nataliia.slyvka@uzhnu.edu.ua

Ірина АНДРУСЯк,

orcid.org/0000-0002-3377-9706

кандидат філологічних наук,

дочент кафедри англійської філології

Ужггородського національного університету

(Україна Ужгород) iryna.andrusiak@uzhnu.edu.иа

\title{
ОСОБЛИВОСТІ ВІДТВОРЕННЯ АНГЛІЙСЬКОЮ МОВОЮ УКРАЇНСЬКИХ ІСТОРИКО-КУЛЬТУРНИХ РЕАЛІЙ РОМАНУ ЮРІЯ АНДРУХОВИЧА «МОСКОВІАДА»
}

\begin{abstract}
Стаття присвячена аналізові особливостей відтворення українських реалій англійською мовою на прикладі роману Юрія Андруховича «Московіада». Метою наукової розвідки є комплексний аналіз відтворення українських історичних реалій у прагматичному та герменевтичному аспектах. Правила іншомовного відтворення українських історичних реалій і власних назв потребують унормування у зв 'язку з існуванням суттєвих розбіжностей наукового бачення у иій сфері. У статті висвітлено необхідність урахування прагматичного аспекту та інтерпретаційного потенціалу з позицій герменевтики при відтворенні історично-культурних реалій у перекладі, аналізуються контекстуальні зв'язки у межах даного текстового матеріалу з метою визначення понятійних меж реалії в ньому. У дослідженні встановлюються і виявляються функціональні та прагматичні аспекти використання і перекладу реалій у художньому творі. Автори зауважують, щзо використання комбінованої реномінації при перекладі реалій дає змогу не лише зрозуміти основне значення лексеми, але й віддзеркалює національну специфіку українського народу. Автори аналізують випадки збереження та порушення колориту географічних та етнографічних реалій при перекладі на англійську мову. Окреслюються основні способи перекладу в романі украӥнських історичних і культурних реалій. Дане дослідження показує, щзо найпоширенішими способами є: комбінована реномінація, описова перифраза, транскрипція та транслітерація, калькування, гіпонімічний переклад. Наукова робота виявляє, щзо комунікативна інтерпретація терміну мови оригіналу і його контекстуальна імплікація залежить великою мірою від трунтовного аналізу контексту та культурного досвіду автора чи перекладача вихідного тексту.
\end{abstract}

Ключові слова: переклад, національно забарвлена лексика, реалія, прагматичний аспект, герменевтичний аспект, транскрипція, комбінована реномація.

Statement of the problem. The language is a reflection of culture and social milieu. In that sense each language is unique and represents the context that is special to it. Reproduction of national identity of the original is one of the central problems in translation studies. Realias as the units whose referential meanings and semantic implications bear the imprint of the Ukrainian cultural and social history life-style cause significant difficulties for translators. The difficulty lies in the fact that there are no direct correspondences which would render specific information and reflect the national colouring at the same time.

Realia words endow literary texts with artistic imagery. The knowledge of the realities of life described in the source text is no less important than the fluency in source language and target language for adequate translation of realias of history and culture of Ukraine. Realia as the problem of translation theory and practice has not been exhausted yet in the comparative investigation. Due to the considerable discrepancies in variety of publications, both books and periodicals, the rules of Ukrainian realia words and proper names translation require standardization. The broad-based study of realia words as well as their functional and cognitive equivalents both in theoretical and practical aspects should be performed in order to create proper standardization. These facts determine the topicality of the study.

Research analysis. Realias in translation have been an object of research of such well-known philologists as A.V.Fyodorov, E.Nida, A.Popovich, I.Levy and others. R. P. Zorivchak published the fundamental monograph devoted specially to realiaS in Ukrainian-English translational contacts in 1989. A noted contribution into the common cause of translating realia has been made by the Ukrainian philologists O.L.Kundzich, I.V.Korunets, V.V.Koptilov, M.O.Novykova, S.Zapolskykh, K.Kyianytsia, 
M.I. Slyvka and other philologists dealing with the problem generally or tackling partially some aspects of the bearers of the national attribution in translation. At present stage, individual attempts are being made to study the major ways and communicative strategies of rendering the nationally colored words and other conceptually loaded elements of history and culture of Ukraine. However, the problem of an appropriate strategy for rendering of temporal features of realias is insufficiently studied.

The article is devoted to the analysis of Ukrainian realia words rendering in translation of literary work of the famous Ukrainian writer on the basis of pragmatic and in the hermeneutic framework. The aim of the investigation is to outline the primary ways of conveying different realias of history and culture of Ukraine in the literary work written by $\mathrm{Yu}$. Andruhovych taking into consideration the pragmatic aspect and interpretive potential from the point of view of hermeneutics in the process of historical realia words translation.

The object of the study is the lexical items that contain Ukrainian background cultural information selected from Yu. Andrukhovych novel "The Moscoviad". The subject of the research is peculiarities of nationally coloured words translation in literary work.

Presenting main material. The nationally coloured words or realias (in the Ukrainian and other post-Soviet terminologies, the word was first used by Fedorov in 1941 "On Belles-lettres Translation") form a subclass of the originally equivalent lacking words that reflect the differences in national cultures, geographical position, historical, social and other peculiarities. In our research we will stick to the following definition of realia - "Realias are mono-and polylexeme units whose primary lexical meaning involves (in the line of the binary opposition) the traditionally fixed in them complex of ethnic and cultural in-formation alien to the objective reality of the target language" (Zorivchak, p.1989: 50).

There are two important aspects that should be taken into account when translating realias: the pragmatic aspect and the interpretation of realias from the perspective of hermeneutics. Awareness of the background information in the original culture plays an important role in translation. In order to reproduce realias adequately, it is necessary to take into account not only the pragmatic aspect, but also to consider them from the point of view of hermeneutics, since it is the only way to understand the content and meaning of what is written and not just to convey lexical and other means formally, but also to compensate for their semantic function. A common feature of the translation models describing the translation process with hermeneutic aspects in mind (the conceptions of E. Koschmieder, W. Koller, as well as D. Seleskovitch and M. Lederer) is the emphasis on the need to identify what is intended (Gemeintes), which acts as a tertium comparationis, and, accordingly, to convey what is intended in the original text by means of the target language (Bodrova-Hozhenmos, 2002: 13). In the broad sense, translation, understanding and interpretation are essentially of the same nature: any understanding is an interpretation, and any translation is a process of understanding and interpretation (Barkhudarov, 1975: 20].

The choice of the object of research is explained primarily by the interest to the fact of the translator's succeeding in adequate representation in the target texts of the parallel (and adjacent in "The Moscoviad") functioning of own (inner) and alien (foreign) (the term of S. Vlahov and C. Florin) realias.

The Polish scholar R. Lyevitsky states that "there is no reason to introduce a distinction between alien realias and own realias. After all, from the point of view of the target language, it is quite immaterial whether in the original language this particular nomination means an "inner" ("native") or an "alien" object, it is foreignness (or lack of it) with respect to the language of translation and the particular culture that is significant" (Lewicki,2000: 50). We do not completely agree with this opinion. Indeed, the work of an interpreter on the reproduction of "inner" or "alien" in relation to the original language realias in most cases does not significantly differ in degrees of difficulty, as in both cases it deals with extremely delicate substance represented by connotative, national and cultural information embodied in realias, however, the translator's comprehension of units belonging to these two categories should not be the same.

Alien (foreign) realias in the original text are always stylistically loaded: they are the author's first tools to depict a geographically, mentally and ideologically remote world which is often unfamiliar for the reader. The world of "The Moscoviad" is Russia, and particularly its capital, Moscow, during the collapse of the USSR. All realias existing in the text are familiar and understood by the reader-fellow countryman of Yu.Andruhovych and his hero Otto von F.

We analyze the means of reproducing of realias in the translation of "The Moscoviad" by Vitaly Chernetsky according to the subject classification offered by S. Vlahov and S. Florin (Vlakhov S., Floryn S., 1986: 59-64). According to the semantic fields, culture-bound words in Yu.Andrukhovych's novel have been classified into the following thematic groups:

a) geographic realias: physical geography; endemic species. 
b) ethnographic realias: anthroponyms, or people's names; words of everyday life; work; art and culture; ethnic objects; tradition and customs terms; measures and money.

c) political and social realias: reginal administrative agencies; ergonyms, or names of institutions and organizations; social and political; history terms; military realia.

The scope of the investigation does not allow to consider the specifics of the reproduction in the English translation of all thematic groups. We define the factors that have an influence on geographic and ethnographic realias translation and determine the role of hermeneutic aspect in terms of realia words rendering.

The culture - bound units in the English version of Yu. Andrukhovych's novel have been classified according to the translation methods used for realia translation elaborated by R. P. Zorivchak. Thus, the following methods of realia translation have been singled out in the process of translation: combined renomination, descriptive paraphrase, transcription (transliteration), situational equivalent, calquing, hyponym translation (generalization), contextual interpretation of the realia (Zorivchak, 1989: 84-150).

The group of geographic realias used in Yuri Andrukhovych's novel "The Moscoviad" includes the names of the Ukrainian towns and cities, the names of the regions and territories, the names of the states and the names of the streets and lanes. The analysis has revealed that that the text under consideration abounds in toponyms, including nominations of countries, cities and towns, names of streets, etc. rendered mainly by means of transliteration or transcription, for example:

Ви в'їдете до Києва на білому кадилаку (Andrukhovych, 2000: 7).

You will enter Kyiv in a white Cadillac (Andrukhovych, 2008: 13).

The method of loan translation (calque), when a source language lexical unit is rendered in such a way that its parts (morphemes or words) are substituted by their direct equivalents in the target language, is represented in the following example:

... Дикого Поля та

Чорного Лісу Архисеньüope (Andrukhovych, 2000: 6)

Vitaly Chernetsky tend to use translation methods in order to provide pragmatically equivalent rendering of Ukrainian realia words.

The following fragment of the text represents an interesting sample for analysis:
Переконуватися в цььому недовго: достатньо пройтися вночі Київським вокзалом і подивитися на цүих сплячих товстих людей у поганому одязі: херсонських, жстомирських, вінницьких, кіровоградських, зачепилівських, зателепанських, замудонських, леніноб(...)ських, дзержниох(...) ських, та - щуотам! - і львівських теж... (Andrukhovych, 2000:, p. 35).

It does not take long to become convinced in this: it is enough to pass through Moscow's Kiev train station at night and look at these sleeping obese and poorly dressed people: from Kherson and Zhytomyr, Vinnytsia and Kirovohrad, some Hookvillesk or Boontownsk, Transballburg, Leninslutsk, Dzerhinopricksk and-alas!-from L'viv as well... (Andrukhovych, 2008: 53).

It is noteworthy that the toponyms "херсонських, житомирських, вінницьких, кіровоградських" аs well as "львівських" are rendered by means of transcription while the coined by the author toponyms "зачепилівських, зателепанських, замудонських, леніноб(...)ських, дзержинох(...)ських" are conveyed with the help of using semi-calque translation simultaneously with employing the tendencies of domestication and foreignization. The method of foreignization lies in the usage of the foreign roots which are usually observed in English and American names of cities, towns and villages: "vill", "town" and "burg", however, the translator adds the inflexion "sk" to domesticize the nominations.

An interesting example of translation is observed in the reproduction of the Soviet derogatory term "совдепія" which is defined as follows in the dictionary: "совдепия - истор., пренебр. РСФСР, СССР; советское государство, советская власть; пережитки советской жизни" (Mokyenko, Nykytyna, 2000: 551).

The translator coins the word "Sovietskiland" which consists of the stem "land" referring to the territory and the stem "Sovietski" which has to convey some derogatory connotations used instead the nomination "the Soviet Union":

Мені коло неї залишалося тільки вдавати зарозумілого іноземного остолопа, який гордовито не розуміє анічогісінько з того, шоо діється в навколишньому совдепіï (Andrukhovych, 2000: 102).

Next to her I had to play a conceited foreign dummy who proudly refuses to understand anything that is going on in the surrounding Sovietskiland (Andrukhovych, 2008: 149).

The same realia used as an attribute to the word "імперія" is, however, translated with the help of substitution with neutral analogue, for example: 
... ией уламок месопотамських імперій, закинутий Космічним Провидінням в імперію совдепівську, за повідомленнями бульварної преси, не так давно святкувала свій день народження ...» (Andrukhovych, 2000: 53).

.. a fragment of Mesopotamian empires cast by Cosmic Providence into the Soviet Empire, recently celebrated her birthday... (Andrukhovych, 2008: 79).

The author spells the word "росія" in one of his passages with a little letter trying to show his derogatory attitude, however, trying to render the denotative meaning of the word which is used by the author to denote the areas of land the translator fails to convey the negative connotation, using the neutral (functional) analogue, for example:

$\epsilon$ дві жінки з глибинних і рівновіддалених від Москви росій (Andrukhovych, 2000: 4).

We have two women from the far - and equidistant from Moscow - Russian lands (Andrukhovych, 2008: 8].

The same method of rendering is applied in the translation of the realia "Великорос" which is used by the author instead of the feminine word "Великоросія". The connotations and additional historical colouring (the nomination was officially used as the name of the country in the $19^{\text {th }}$ - the beginning of the $20^{\text {th }}$ century) of the word is not preserved in the translation:

Дві жінки, дві квітки з глибинних провіниій Великороса (Andrukhovych, 2000: 4).

Two women, two flowers from the far provinces of Russia (Andrukhovych, 2000: 8).

The group of ethnographic realias includes anthroponyms, or people's names, anthroponyms denoting historical figures, words of everyday life, names of clothes, dishes, beverages, nominations of art and culture etc. The group under study is not homogenous. It includes inner Ukrainian (e.g. пляики, сушениці, самогон, горілка, трембітарі, кобзарі, гуиули, бойки, колиба, слоїк ) alien Russian (водка, сарафани, кокошники, кубанка, косоворотка, валянки) and Soviet realias (рубль, ленін, Ленін, Хрущов) which at one time were a part of the common Soviet culture.

It should be noted that the names of characters are usually conveyed by means of transcription and transliteration, for instance: Омелян ПорфировичOmelyan Porfyrovych; Люба- Lyuba; КирилоKyrylo.

An interesting case is represented by the following fragment which contains two surnames translated by means of transcription, however, the Ukrainian surname «Горобець» is rendered with the help of the letter " $h$ " while the Russian surname «Голіцин» is rus- sified and rendered with the help of the letter "g" to impart its Russian sounding notwithstanding the fact that in the original text both surnames are spelt with the help of the Ukrainian «Гॅ» but not «I »:

- Яка твоя нація, Горобець? - вимагає правди Голіцин (Andrukhovych, 2000: 27).

"What's your nationality, Horobets?" asks Golitsyn demanding the truth (Andrukhovych, 2008: 41].

The inner ethnographic realias relating to everyday life include nominations of dishes and beverages. In a work we have come across an interesting example to consider. That is the translation of the word "пляцок". The explanatory Ukrainian dictionary states that "пляцок" means "корж (Busel, 2004: 800). This lexeme is marked "3ax.", thus indicating that the area of functioning of the word in this sense is western Ukraine. If we turn to the translation, we see that in the English version this realia is rendered by descriptive paraphrase reproduced as "potato pancakes" (Andrukhovych, 2008: 55], which is translated "картопляні млинці" in the reverse translation but by no means "cakes" - "коржі" (the word "корж" is defined in explanatory Ukrainian dictionary as "плоский круглої форми виріб із прісного тіста" (Busel,2004: 893). Should we consider the translation of this lexeme as semantically wrong? Let us perform a little linguistic investigation on the material of Western media. In one of the periodicals we find the phrase "смажу свої пляцки з бульби”. Thus, it should be noted that the dictionary definition of the word "пляцка" reveals only one of its meanings. The acceptability of the translator's variant is proved by the context of the original text. The source text contains the following utterance: " $О$, пляцки - то божественне їдло - втішився Немирич. -Прошу шість пориій з грибовим соусом!" (Andrukhovych, 2000: 57).

Since the character orders the dish with mushroom sauce, it is obvious that it was not sweet. It is not known for sure whether they were potato pancakes, instead of corn, for example, but the correctness of the translator's thought is undeniable. Certainly, it does not mean that a particular method of translation is applied to all lexemes of this group, since each nationally coloured word requires an individual translators approach.

Conclusions. Insufficient awareness of history, culture, traditions, social order, political life, can result in inadequate translation which can fail to be perceived by the recipient or be perceived in a wrong way. The hermeneutical aspect of translation includes the issue of the translator's understanding and interpretation of the original text and the issues of the recipient's understanding and interpretation $n$ of the 
translated text. There is no doubt that the translator's understanding of the original text is a prerequisite for successful translation.

The word semantics and hermeneutic approach to realia interpretation allow us to obtain a clear-cut picture of the functional peculiarities of each realia word. The results of the research allow to state that geographic realias are translated by a range of translation methods, including: transcription and transliteration, semicalque, calque, combined renomination, descriptive paraphrase. The group of ethnographic realias is mostly rendered by descriptive paraphrase, functional analogue and transcription or transliteration. Each historical realia word requires an individual translation approach. Different realias of history and culture of Ukraine may acquire entirely different meanings and various functions in different contexts even if it refers to the same thing or phenomenon. To translate properly nationally coloured words one must first of all know what information the unit possesses in the language as a system and bears in the definite context. To choose the right way of rendering nationally coloured names one must study wider context and take into consideration extralinguistic situation of communication.

The perspective of the further research is seen in the contrastive study of Ukrainian realias used in Yu. Andrukhovych's other novels translated into the English language ("Perversion", "Twelve Rings", "Recreations", etc.) as well as the contrastive research of realias used in the original work as well as their translations into different languages (English, German and Polish). Prospects for further research are seen in the analysis of certain translation failures in the conveying and to offer the best options for their translation.

\section{BIBLIOGRAPHY}

1. Андрухович Ю. Московіада. Роман жахів. Івано-Франківськ: Лілея-НВ, 2000. 140 с.

2. Бархударов Л.С. Язык и перевод: вопросы общей и частной теории перевода. М: Международные отношения, 1975. $240 \mathrm{c}$

3. Бодрова-Гоженмос Т.И. Процесс перевода с точки зрения интерпретативной теории. Социокультурные проблемы перевода: сб. науч. трудов. 2002. Вып. 5. С. 11-19.

4. Бусел В. Великий тлумачний словник української мови.К: ВТФ "Перун", 2004. 1440 с.

5. Влахов С. Флорин С. Непереводимое в переводе. М: Висша шк., 1986. 416 с.

6. Зорівчак Р. П. Реалія і переклад:монографія. Львів, 1989. 216 с.

7. Мокиенко В., Никитина Т. Большой словарь русского жаргона. Норинт, 2000. 716 с.

8. Lewicki R. Obcosc w odbiorze przekladu. Lublin: Wydawnictwo Uniwersytetu Marii Curie-Sklodowskiej, 2000. $172 \mathrm{~s}$.

9. Andrukhovych Yu. The Moscoviad. [Translated by Vitaly Chernetsky]. NY: Spuyten Duyvil, 2008. 189 p.

\section{REFERENCES}

1. Andrukhovych Yu. Moskoviada. Roman zhakhiv [The Moscoviad horror novel.] Ivano-Frankivsk: Lileia-NV, 2000. 140 s. [in Ukrainian].

2. Barkhudarov L.S. Yazyik i perevod: voprosyi obschey i chastnoy teorii perevoda [Language and translation: issues of general and special theory of translation]. M: Mezhdunarodnyie otnosheniya, 1975. $240 \mathrm{~s}$. [in Russian].

3. Bodrova-Hozhenmos T.Y. Protsess perevoda s tochki zreniya interpretativnoy teorii. [The process of translation from the point of view of interpretive theory. Sociocultural problems of translation]: sb. nauch. trudov. 2002. Vыр. 5. S. 11-19. [in Russian].

4. Busel V. Velykyi tlumachnyi slovnyk ukrainskoi movy [The explanatory dictionary of the Ukrainian language]. K: VTF "Perun", 2004. 1440 s. [in Ukrainian].

5. Vlakhov S. Floryn S. Neperevodymoe v perevode [Untranslatable lexical units in translation]. M: Vyssha shk., 1986. 416 c. [in Russian].

6. Zorivchak R. P. Realiia i pereklad:monohrafiia [Realia and translation: monograph]. Lviv, 1989. 216 c. [in Ukrainian].

7. Mokyenko V., Nykytyna T. Bolshoi slovar russkoho zharhona [Gross dictionary of Russian jargon]. Norynt, 2000. 716 s. [in Russian].

8. Lewicki R. Obcosc w odbiorze przekladu. [Foreignness in the reception of the translation] Lublin: Wydawnictwo Uniwersytetu Marii Curie-Sklodowskiej, 2000. 172 s. [in Polish].

9. Andrukhovych Yu. The Moscoviad. [Translated by Vitaly Chernetsky]. NY: Spuyten Duyvil, 2008. 189 p. 